https://cyberleninka.ru/article/n/mezhfirmennaya-kooperatsiya-kak-faktor-innovatsionnogo-razvitiya 11.07.2020). [in Ukrainian].

9. Gal`kiv L.I. Sanatorno-kurortna diyal`nist`: ry`nok poslug sanatoriyiv u regionax Ukrayiny`[Sanatorium-resort activity: the market of sanatorium services in the regions of Ukraine]/ L.I. Halkiv, Ya. Kuly'nyak, M.V. Gerbut// Bulletin of the National University "Lviv Polytechnic". Series: Problems of economics and management. - Lviv: Lviv Polytechnic Publishing House, 2017. - Issue 873. - P. 18-26.] [in Ukrainian].

10. Knyaz O.V. Analiz ta ocinyuvannya faktoriv, yaki vply`vayut` na riven` innovacijnogo rozvy tku pidpry`yemstv [Analysis and evaluation of factors that affect the level of innovative development of enterprises]. Economics of Industry. - 2006. - № 3. - P. 128-135. [in Ukrainian].

11. Ryadno, O. A., \& Berkut, O. V. (2016). Doslidzhennya struktury` ta dy`namiky` dy`ferenciaciyi social`no-ekonomichnogo rozvy`tku regioniv Ukrayiny` na osnovi klasternogo analizu [Research of structure and dynamics of differentiation of social and economic development of regions of Ukraine on the basis of the cluster analysis.] Economic Bulletin of Donbass, (1), 6067. [in Ukrainian].

12. Yermak, S. O. (2017). Klasterny’j analiz regioniv Ukrayiny`za klyuchovy`my` indy katoramy` rivnya innovacijnogo rozvy`tku [Cluster analysis of the regions of Ukraine according to key indicators of the level of innovative development]. Economics of Development, (3), 34-43.]

13. Metodolohichni polozhennia zi statystyky innovatsiinoi diialnosti (u redaktsii nakazu Derzhavnoi sluzhby statystyky Ukrainy [Methodological provisions for statistics of innovative activities (for the editors of the State Statistics Service of Ukraine] 28.12.2015, № 369 ), 4. [in Ukrainian].

14. Lapach S.N., Chubenko A.V., Baby`ch P.N. Staty`sty`ka v nauke y` by`znese.[Statistics in science and business]. - Kyiv: MORION, 2002. - 640 p. [in Russion].

1. Ekonomichny`j Efekt IT-Galuzi L`vova Syagnuv Rekordnoyi Sumy` - Majzhe Mil`yard Dolariv. [15. Economic Effect of Lviv's IT Industry Reached a Record Amount - Almost a Billion Dollars. Retrieved from: https://itcluster.lviv.ua/ekonomichnyj-efekt-galuzi-lvova-syagnuv-rekordnoyi-sumy-majzhe-milyard-dolariv/

Дата подання публікації 22.08.2020 p.

УДК 322.122

Подзізей О.О., аспірант

Podzizei O. O., PhD student

https://orcid.org/0000-0002-3646-7687

\title{
ОСОБЛИВОСТІ ФОРМУВАННЯ КОНКУРЕНТОСПРОМОЖНОСТІ ОТГ НА ЗАСАДАХ СТАЛОГО РОЗВИТКУ
}

\author{
Східноєвропейський національний університет імені Лесі Украӥнки
}

Особливості сучасного етапу реформування системи місцевого самоврядування, а також, пов'язаної з цим трансформації принципів економічної політики та бюджетної децентралізації, що відбувається в Україні, потребують перегляду усіх системних факторів, які визначають особливості функціонування низової ланки адміністративно-економічного устрою держави. В даному аспекті принципово новим, а також базовим елементом такої системи стають об'єднані територіальні громади (ОТГ), які формуються в процесі реалізації нової державної політики - децентралізації органів місцевого самоврядування та підвищення ролі місцевих громад в забезпеченні потреб їх соціально-економічного розвитку.

В статті розглянуто сучасні особливості формування та забезпечення ефективності функціонування системи об'єднаних територіальних громад, як нових суб'єктів регіонального управління в системі ринкових відносин. Визначено, що проблема забезпечення ефективності діяльності ОТГ значною мірою залежить від рівня їх конкурентоспроможності. При цьому найголовнішими елементами, які визначають конкурентоспроможність територіальної громади, $є$ забезпеченість ресурсами, інвестиційний клімат та фінансова стійкість територіальних громад. Досліджено, що реалізація завдань адміністративної та бюджетної децентралізації, що проходить в Україні, неможлива без формування насправді дієвих та ефективних територіальних громад Визначено ефективність застосування інтегрованої схеми формування конкурентоспроможності об'єднаних територіальних громад, яка включає не лише формування системи надходжень до бюджетів ОТГ, але й забезпечує розвиток головних напрямків інвестування цих ресурсів інновацій, системи комунікацій, людського капіталу, інфраструктури. Запропоновано авторський підхід до трактування поняття конкурентоспроможності об'єднаних територіальних громад 3 точки зору системного підходу до врахування усіх ключових складових та елементів ії забезпечення.

Ключові слова: ОТГ, ефективність, конкурентоспроможність, децентралізація, сталий розвиток. 


\title{
PECULIARITIES OF UTC COMPETITIVENESS FORMATION ON THE BASIS OF SUSTAINABLE DEVELOPMENT
}

\author{
Lesya Ukrainka Eastern European National University
}

\begin{abstract}
The peculiarities of the current stage of reforming the system of local self-government, as well as the involvement of the principles of economic policy and budget decentralization in Ukraine, require an overview of all systemic factors that determine the functioning of the grassroots administrative and economic development. In this aspect, a fundamentally new and basic element of such a system are created united territorial communities (UTC), which are formed in the process of implementing a new state policy - decentralization of local government and increasing the role of civil society in meeting their socio-economic development.

In articles modern features of formation and maintenance of efficiency of functioning of systems of the united territorial communities as new subjects of regional management in system of market relations are considered. It is determined that the problem of ensuring the efficiency of UTC activities largely depends on the level of their competitiveness. According to this, the most important elements that determine the competitiveness of the local community are the availability of resources, investment climate and financial stability of local communities. It is investigated that the implementation of the tasks of administrative and budgetary decentralization that takes place in Ukraine is impossible without the formation of management tools for effective and efficient territorial public organizations. to promote the development of the main areas of investment of these resources - innovation, communication systems, human capital, infrastructure. The author's approach to the interpretation of the concept of competitiveness of the opportunities of the united territorial communities from the point of view of the system approach to the management of all key structures and elements of its provision is offered.
\end{abstract}

Keywords: UTC, efficiency, competitiveness, decentralization, sustainability.

Постановка проблеми у загальному вигляді та ії зв'язок 3 важливими науковими та практичними завданнями. Підвищення конкурентоспроможності ОТГ нерозривно пов'язане з процесами забезпеченням соціально-економічного розвитку територій. Це означає, що органи місцевого самоврядування зобов'язані керуватися в своій діяльності принципами не лише адміністративного управління, але й враховувати особливості взаємодії з суб'єктами господарювання, що діють на цій території, місцевим населенням, яке має певні визначені потреби щодо розвитку територіальної громади, а також - враховувати необхідність взаємодії з іншими ОТГ і органами державного управління для забезпечення гармонійного розвитку усього відповідного регіону, а також - для формування відповідної концепції ефективного функціонування об'єднаної територіальної громади в аспекті забезпечення її конкурентоспроможності.

Таким чином, проблематика забезпечення ефективності функціонування об'єднаних територіальних громад значною мірою залежить від рівня їх конкурентоспроможності і набуває особливої актуальності, перш за все, в аспекті необхідності забезпечення підвищення цієї конкурентоспроможності для забезпечення процесів сталого розвитку відповідних територій.

Аналіз останніх досліджень і публлікацій, у яких започатковано вирішення даної проблеми. Проблематика забезпечення належного функціонування нової системи об'єднаних територіальних громад, що утворюються в процесі адміністративного реформування в Україні, достатньо широко розкрита в працях таких українських дослідників даного наукового напрямку, як Б. М. Андрушків, Н. Б. Кирич, С. М. Кльоба, М. А. Латинін, О. Б. Погайдак, С. М. Співак та інші. Також варто відзначити значний вклад в дослідження специфіки функціонування та розвитку систем регіонального управління таких зарубіжних дослідників, як П. Кругман, Р. Лукас, Е. Прескотт, Д. Родрік тощо. В той же час, специфіка сучасного етапу розвитку регіональних економічних систем значною мірою залежить від специфіки проведення адміністративних змін та бюджетної децентралізації що, на наш погляд, потребує поглибленого дослідження питань формування конкурентоспроможності об'єднаних територіальних громад в Україні.

Цілі статті. Метою роботи є дослідження сучасної специфіки формування конкурентоспроможності ОТГ та забезпечення ефективності їх функціонування в 
аспекті проведення адміністративно-економічної реформи децентралізації системи місцевого самоврядування. Також дослідження передбачає формування підходів до формування конкурентоспроможності об'єднаних територіальних громад з врахуванням потреби у забезпеченні інтенсифікації розвитку місцевих громад та відповідних регіонів держави.

Викладення основного матеріалу дослідження 3 повним обгрунтуванням отриманих наукових результатів. Процес формування поняття конкурентоспроможності ОТГ, як комплексного підходу по створенню системи позитивних факторів регіонального розвитку місцевого самоврядування повинен включати в себе ряд ключових елементів, а саме:

- економічний потенціал громади;

- рівень технологічного розвитку території;

- доступ до інвестиційних ресурсів;

- наявність природніх ресурсів, включаючи рекреаційні;

- наявність інноваційної складової в плані розвитку ОТГ.

При цьому, як зазначає Б. Андрушків: «Конкурентоспроможність громади формується завдяки ефективному використанню та управлінню виробничого, фінансового, науково-технічного, інноваційно-інвестиційного, майнового, кадрового потенціалу. Тому формування територіальної громади повинне перш за все базуватися на принципах рівномірного розподілу, щоб заздалегідь виключити можливість створення неефективних, неспроможних об'єднань територіальних громад, які не зможуть забезпечити розвиток адміністративно-територіального утворення» [1, с. 4]. Як бачимо, комплексна природа формування конкурентоспроможності об'єднаних територіальних громад визначається як на рівні адміністративного управління, так і в аспекті формування належної ресурсної бази розвитку територій, а також - системи управління соціально-економічними процесами.

Відповідно, можна стверджувати, що конкурентоспроможність ОТГ визначається загальним рівнем соціально-економічного розвитку місцевої громади та плановими завданнями щодо його розвитку. Тобто можна вести мову про формування моделі конкурентоспроможності ОТГ, яка повинна бути спрямована на задоволення потреб місцевих громад в системі комплексного плану інклюзивного розвитку відповідного регіону, тобто включати в себе як потреби, так і можливості забезпечення відповідних девелоперських завдань громади (рис. 1).

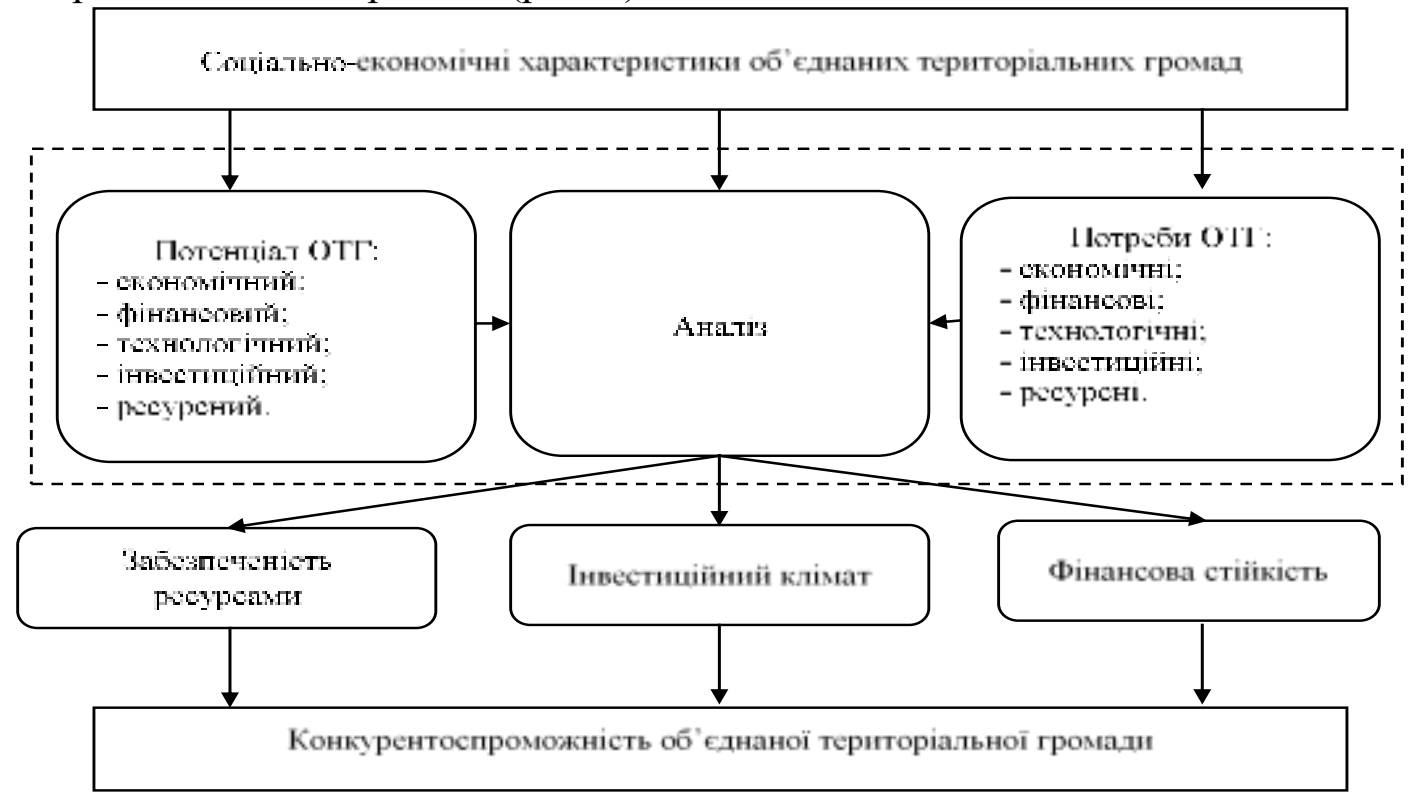

Рис. 1. Модель забезпечення конкурентоспроможності ОТГ Джерело: [1, с. 5]. 
Таким чином ми приходимо до висновку, що забезпечення конкурентоспроможності ОТГ потребує реалізації комплексу заходів, спрямованих на інтенсифікацію розвитку усіх сфер діяльності об’єднаних громад i, одночасно, узгоджених та уніфікованих із завданнями та потребами регіонального розвитку. При цьому виникає природня потреба конкретизації таких заходів, оскільки без деталізованого їх переліку реалізація планів посилення конкурентоспроможності буде стикатися $з$ очевидними труднощами щодо спрямування зусиль та ресурсів, що може призвести до негативних результатів. Значну увагу в даному аспекті варто приділити також фактору використання людських ресурсів громади, оскільки «забезпечення нормальних умов відтворення робочої сили, налагодження механізму цього відтворення покликане стабілізувати ситуацію, що склалася на регіональному ринку праці в Україні» $[2$, c. 84$]$.

Таким чином конкретна конкурентна позиція об’єднаних територіальних громад в системі соціально-економічного розвитку територій визначається переліком різнопланових чинників, які у своїй сукупності конкретизують загальні фактори формування конкурентоспроможності територіальної громади і мають різноплановий вплив на сам процес розвитку ОТГ. Втім, варто зазначити, що з іншого боку, дані чинники не є відособленими від загальної стратегії розвитку територіальних громад, адже вони характеризують собою саме ті напрямки, в яких і повинен зосереджуватися стратегічний план розвитку ОТГ, як таких. Відтак, можна стверджувати, що чинники конкурентоспроможності ОТГ являють собою конкретний перелік умов, за яких $\epsilon$ можливим якісний розвиток та загальне підвищення ефективності функціонування об’єднаних територіальних громад.

Відповідно конкурентоспроможність ОТГ пов'язана з необхідністю забезпечення належного рівня розвитку самої територіальної громади. При цьому необхідно зазначити, що суто статичне благополуччя певної ОТГ щодо умов інфраструктури аби доступу до певних конкурентних переваг в конкретний момент часу не є визначальними для загального успіху, оскільки саме забезпечення конкурентоспроможності ОТГ можливе лише в умовах постійного динамічного зростання як самих конкурентних переваг, так і формування гарантій забезпечення їх належного розвитку в майбутньому, що покращуватиме умови функціонування самих ОТГ i сприятиме формуванню належного рівня їх конкурентних переваг за рахунок постійного удосконалення.

Тому, в даному аспекті, на нашу думку необхідно виділити наступні компоненти системи забезпечення конкурентоспроможності об'єднаних територіальних громад:

- формування системи забезпечення ефективності функціонування елементів економічної та соціальної інфраструктури в регіоні, забезпечення належного доступу та підвищення ефективності використання систем транспортної доступності ОТГ;

- сприяння загальному розвитку підприємницьких структур на території місцевих громад та налагодження співпраці 3 місцевим бізнесом зі сторони адміністративних структур місцевого самоврядування та державного управління;

- формування прозорої системи управління фінансовими ресурсами територіальної громади з метою забезпечення ефективності їх управління та задоволення інвестиційних потреб громади;

- формування планів розвитку виробництва на території місцевих громад 3 обов'язковим узгодженням їх відносно дотримання вимог екологічної безпеки регіону;

- формування стратегії забезпечення конкурентоспроможності ОТГ шляхом формування довгострокових планів інклюзивного розвитку територій місцевих громад;

- забезпечення належного інвестиційного клімату та пошук нових інвесторів шляхом сприяння розвитку бізнесу та залученню підприємницьких структур до вирішення питань розвитку місцевих громад;

- відкритість діяльності органів місцевого самоврядування перед місцевою громадою та представниками бізнесу, створення систем прозорого та дієвого контролю діяльності цих органів з боку місцевого населення та суб’єктів економічної діяльності. 
Отже, описані елементи забезпечення конкурентоспроможності ОТГ у своїй сукупності дають змогу сформувати комплексну схему цієї конкурентоспроможності i, таким чином, визначити взаємозв'язок між усіма іiі ключовими складовими, 3 врахуванням специфіки регіональних особливостей територіальних громад в аспекті забезпечення їх сталого розвитку (рис. 2).

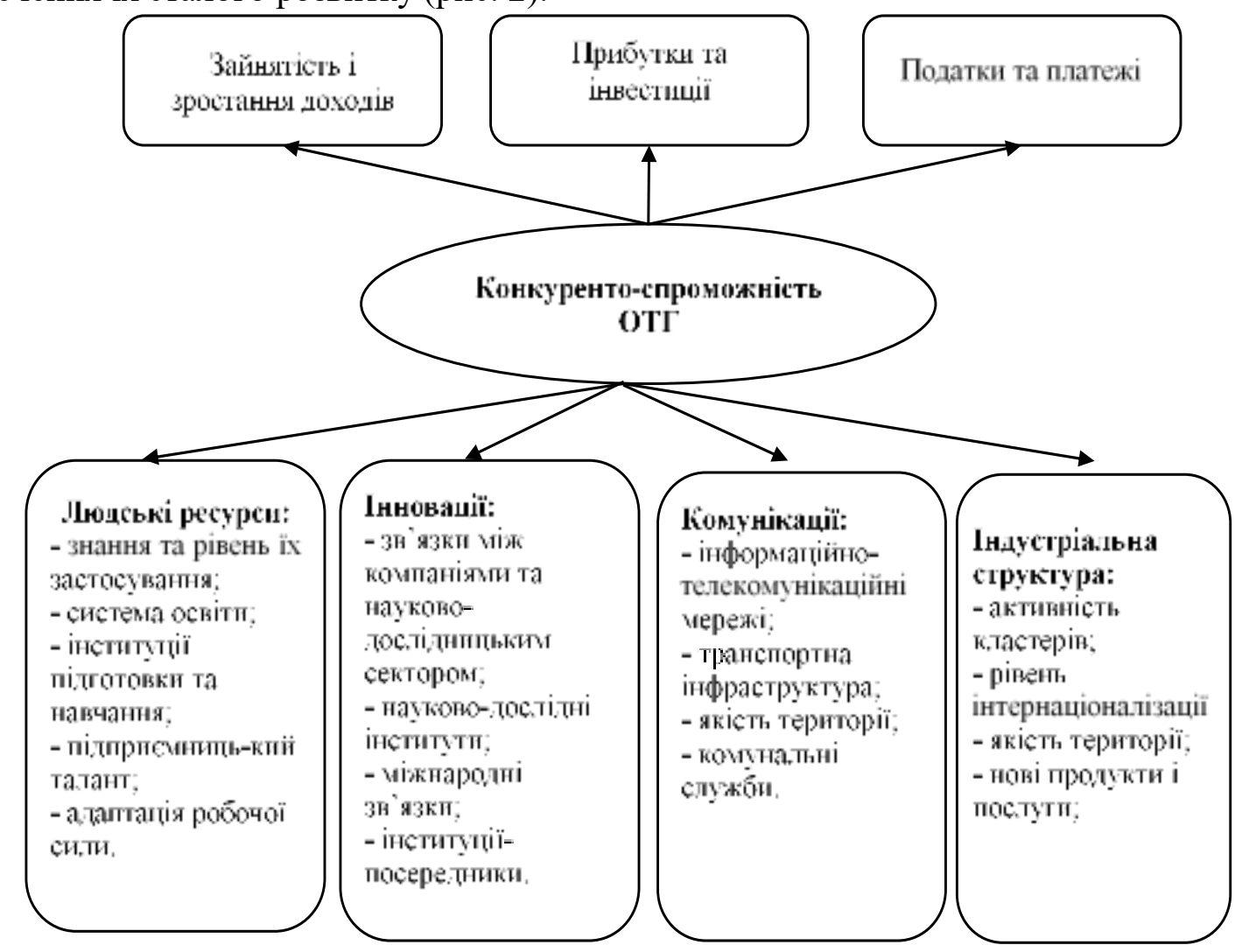

Рис. 2. Схема формування конкурентоспроможності об'єднаних територіальних громад

Джерело: [3, с. 29].

Отже, можна стверджувати, що на основі схеми типових заходів та рішень щодо формування конкурентоспроможності об'єднаних територіальних громад виникає можливість для органів місцевого самоврядування для формування дієвих планів розвитку ОТГ як в коротко-, так і у довгостроковій перспективі. При цьому необхідно враховувати, що запропонована схема має відносно універсальний характер і тому потребує вдосконалення в межах конкретизації умова і завдань розвитку кожної окремої територіальної громади в залежності від особливостей ії територіального розташування та уже наявних елементів необхідної інфраструктури, які для різних громад можуть досить сильно відрізнятися.

Підсумовуючи проведений аналіз теоретико-методологічного інструментарію розуміння сутності конкурентоспроможності ОТГ, приходимо до висновку здійснити узагальнення розуміння даного поняття 3 врахуванням специфіки та методології забезпечення формування конкурентоспроможності громад та необхідності стимулювання іiі постійного підвищення задля забезпечення ефективного їх розвитку.

Відповідно, пропонується розглядати конкурентоспроможність ОТГ, як систему забезпечення економічних, фінансових, технологічних, інвестиційних та інших ресурсних переваг територіальної громади, яка дозволяє ій самостійно реалізовувати 
перспективні плани соціально-економічного розвитку з врахуванням необхідності взаємодії з іншими громадами та відповідного регіону в цілому.

Висновки. Таким чином реалізація завдань по забезпеченню формування конкурентоспроможних ОТГ значною мірою залежить від ефективності функціонування органів місцевого самоврядування, які в процесі своєї діяльності повинні дотримуватися рекомендованих принципів формування конкурентоспроможності 3 максимальним врахуванням усіх факторів та чинників, що випливають на цей процес як в соціальній, так і в економічній сфері.

Отже, можна стверджувати, що реалізація завдань адміністративної та бюджетної децентралізації, що проходить в Україні, неможлива без формування насправді дієвих та ефективних територіальних громад, які в довгостроковій перспективі повинні забезпечити ефективний та сталий розвиток відповідних територій за рахунок досягнення високого рівня власної конкурентоспроможності.

\title{
Список бібліографічного опису
}

1. Андрушків Б. М., Кирич Н. Б., Латинін М. А., Погайдак О. Б., Співак С. М. Особливості формування добровільних конкурентоспроможних об’єднань територіальних громад в умовах децентралізації: проблеми та перспективи моделювання процесу. Теорія та практика державного управління. 2017. №2 (57). С. 1-8.

2. Дзямулич М. І. Механізм відтворення робочої сили в аспекті ринкових трансформацій. Економіка: проблеми теорії та практики. Збірник наукових пращь. Випуск 125. Дніпропетровськ: ДНУ, 2002. С. 73-84.

3. Кльоба С. М. Економічна оцінка розвитку та конкурентоспроможності об'єднаних територіальних громад Львівської області. Економічний аналіз. 2018. Том 28. № 3. С. 27-36.

\section{References}

1. Andrushkiv B. M., Kyrych N. B., Latynin M. A., Pogajdyk O. B., Spivak S. M. Osoblyvosti formuvannia dobrovilnyh konkurentospromozhnyh ob'ednan terytorialnyh gromad $\mathrm{v}$ umovah dezentralizazii: problem ta perspektyvy modeliuvannia procesu [Peculiarities of formation of voluntary competitive associations of territorial communities in the conditions of decentralization: problems and prospects of process modeling]. Theory and practice of public administration. 2017. Vol 2 (57). Pp. 1-8 [in Ukrainian].

2. Dziamulych M. I. Mehanizm vidtvorennia robochoi syly v aspekti rynkovyh transformacij [The mechanism of labor reproduction in the aspect of market transformations]. Economics: problems of theory and practice. 2002. Vol. 125. Pp. 73-84 [in Ukrainian].

3. Klioba S. M. Ekonomichna ocinka rozvytku ta konkurentospromozhnosti ob'ednanyh terytorialnyh gromad L'vivskoi oblasti [Economic assessment of the development and competitiveness of the united territorial communities of Lviv region]. Economic analysis. 2018. Vol. 28 (3). Pp. $27-36$ [in Ukrainian].

Дата подання публікації 10.09.2020 р.

УДК 322.122

Шматковська Т.О., к.е.н., доцент Shmatkovska T., PhD in Economics, Associate Professor https://orcid.org/0000-0003-2771-9982

Подзізей О.О., аспірант Podzizei O. O., PhD student https://orcid.org/0000-0002-3646-7687

\section{КОНЦЕПТУАЛЬНІ ЗАСАДИ ПІДВИЩЕННЯ КОНКУРЕНТОСПРОМОЖНОСТІ ОБ'ЄДНАНИХ ТЕРИТОРІАЛЬНИХ ГРОМАД}

\author{
Східноєвропейський наџіональний університет ім. Лесі Украӥнки
}

\begin{abstract}
Особливості забезпечення конкурентоспроможності об'єднаних територіальних громад, безумовно, мають свою специфіку стосовно впливу на іiі формування з богу адміністративних органів держаного управління. 3 іншого боку, конкурентоспроможність не може розглядатися як окремий показник чи характеристика, оскільки за своєю сутністю вона є динамічною. Якщо проводити аналогію 3 товарним ринком, то можна стверджувати, що будь-який товар або послуга на певному етапі свого
\end{abstract}

